3 - ORIGINAL ARTICLE

\title{
Jaundice in second intention wound healing in rats ${ }^{1}$
}

\author{
Icterícia na cicatrização por segunda intenção em ratos
}

\author{
Maria de Lourdes Pessole Biondo-Simões ${ }^{2}$, Celso Fernando Ribeiro Araújo ${ }^{3}$, João \\ Henrique, Felício de Lima ${ }^{4}$, Marcelo Ferreira ${ }^{4}$, Marcos de Abreu Bonardi ${ }^{4}$
}

1. Study carried out at the Discipline of Surgical Technique and Experimental Surgery, Department of Surgery, Faculty of Medicine, Federal University of Paraná (UFPR).

2. PhD of Medicine. Coordinator, Discipline of Surgical Technique and Experimental Surgery, UFPR and Professor, Pontifícia Universidade Católica do Paraná (PUCPR).

3. Professor of Department of Surgery, UFPR.

4. Medical Residents, Department of Surgery, University Hospital, UFPR.

\begin{abstract}
PURPOSE: The objective of the present study was to monitor the process of second intention skin wound healing in rats with jaundice.

METHODS: The study was divided into two steps. In the first, obstructive jaundice was induced in 68 male rats to investigate the biochemical changes and to determine the ideal time for the study of healing. In the second step, 54 rats were divided into two groups: control (normal) and experimental (jaundiced). Seventy-two hours after jaundice induction, a standardized wound was produced in the dorsum by removing the skin and the subcutaneous net, whose contraction was assessed on the $3^{\text {rd }}, 7^{\text {th }}, 10^{\text {th }}$ and $14^{\text {th }}$ day and monitored with a computer program. After sacrifice, the tissue was submitted to histopathologic analysis.

RESULTS: The most marked biochemical changes were detected between the $3^{\text {rd }}$ and $5^{\text {th }}$ day. The reduction of he wound area was slower in the jaundice group at all 4 time points studied $\left(\mathrm{p}_{3}=0.0366, \mathrm{p}_{7}=0.0054, \mathrm{p}_{10}=0.0000 . \mathrm{p}_{14}=0.0000\right)$. Collagen concentration was lower in the wound of jaundiced animals $\left(\mathrm{p}_{3}=0.0000 . \mathrm{p}_{7}=0.0000 . \mathrm{p}_{14}=0.0000\right)$.

CONCLUSION: Jaundice delays collagen deposition and maturation and wound contraction in wounds left to heal by second intention wound healing in rats.
\end{abstract}

Key words: Wound healing. Jaundice.

\section{RESUMO}

OBJETIVO: O objetivo do presente estudo foi monitorar o processo de cicatrização, por segunda intenção em ratos com icterícia.

MÉTODOS : O estudo foi dividido em 2 etapas. Na primeira, icterícia obstrutiva foi induzida em 68 ratos machos para investigação das mudanças bioquímicas e para determinação do momento ideal para o estudo da cicatrização. Na segunda etapa, 54 ratos foram divididos em dois grupos: controle (normal) e experimental (ictérico).Setenta e duas horas após a indução da icterícia, uma lesão padrão foi produzida na região dorsal dos animais com a remoção da pele e da tela 
subcutânea. A contração da ferida foi mensurada no $3 .^{\circ}, 7 .^{\circ}, 10 .^{\circ}$ e $14 .^{\circ}$ dia e monitorada com programa computadorizado. Após a eutanasia, os tecidos da área de cicatrização foram submetidos a análise histopatológioca.

RESULTADOS: As alterações bioquímicas mais marcantes foram detectadas entre o $3 .^{\circ}$ e o $5 .^{\circ}$ dia. A redução da área da ferida foi menor no grupo ictérico nos 4 tempos estudados $\left(\mathrm{p}_{3}=0.0366\right.$, $\left.\mathrm{p}_{7}=0.0054, \mathrm{p}_{10}=0.0000 . \mathrm{p}_{14}=0.0000\right)$ e a concentração de colágeno foi menor nas feridas destes animais $(\mathrm{p}=0.0000)$.

CONCLUSÃO: A icterícia diminui a concentração de colágeno, a maturação e a contração das feridas deixadas para cicatrizar por segunda intenção, em ratos.

Descritores: Cicatrização de feridas. Icterícia.

\section{Introduction}

Jaundice has been repeatedly recognized as a factor impairing surgical wound healing. Keill et $\mathrm{al}^{1}$ reported a similar number of abdominal wound dehiscences in icteric and anicteric patients, while Ellis, Heddle ${ }^{2}$ observed a $33.3 \%$ frequency of complications such as dehiscence and hernia in icteric patients compared to $5.2 \%$ in anicteric patients $(p=0.0002)$. Irvin et $\mathrm{al}^{3}$ found a $27.1 \%$ frequency of abdominal wound complications in icteric patients but only a $4.3 \%$ frequency in anicteric subjects $(\mathrm{p}<0.0001)$. Armstrong et at followed up 1133 patients and found a higher incidence of dehiscence and incisional hernia $(\mathrm{p}<0.0005)$ in those with hyperbilirubinemia. Grande et at ${ }^{5}$ confirmed an association between jaundice and a higher frequency of abdominal wound healing complications, but called attention to the fact that this was only true for patients with malignant disease.

Hyperbilirubinemia has been shown to exert some effects on wound healing. Lee ${ }^{6}$, in a study on rats with induced jaundice, observed a reduced migration of reticuloendothelial cells and fibroblasts, with collagen deficiency and, thus, deficient healing ${ }^{6}$. Bayer, Ellis ${ }^{7}$ studying abdominal wall healing in rats, found dense and ordered collagen in normal animals on day 8 after surgery, while jaundiced animals showed a marked inflammatory infiltrate containing young fibroblasts, minimal collagen formation and rare neovascularization.

$\operatorname{Than}^{8}$ reported an important loss in the capacity of the skin to withstand tension in animals with jaundice. In contrast, Greaney et al observed that, although animals with jaundice presented a lower collagen concentration $(\mathrm{p}<0.01)$, their capacity to withstand tension was unaltered. 
Taube et $\mathrm{al}^{10}$ showed that the addition of bilirubin to fibroblast cultures led to histological modifications and a reduced replication rate. Dawiskiba et $\mathrm{al}^{11}$ observed in jaundice rats that both the early and late healing phases were affected, leading to a loss of resistance of the wounds accompanied by reduced proliferation of fibroblasts and endothelial cells, as well as a low collagen concentration.

In a recent study carried out in our laboratory, we observed a lower concentration of total collagen and collagen fractions I and III in jaundiced animals during the initial phases of skin healing up to day 7. During the later phases, total collagen and collagen I concentrations continued to be lower in jaundiced animals, demonstrating a delay in collagen synthesis and maturation $^{12}$.

Studies reported in the literature and those carried out in our laboratory have thus far only approached wounds treated by first intention; however, since icteric patients present more skin dehiscence, how do wounds heal that are left for restoration by second intention? The objective of the present study was to monitor the process of healing by second intention in rats.

\section{Methods}

The present investigation was carried out according to the guidelines of the Brazilian College of Animal Experimentation (COBEA), an institution affiliated with the International Council for Laboratory Animal Science and Federal Brazilian Law 6.638.

The study was divided into two stages: during the first stage, biochemical alterations caused by jaundice were analyzed to establish the ideal time for carrying out the second stage during which healing by second intention was monitored.

For the first stage, 68 male rats (Rattus norvegicus albinos, Rodentia mammalia) aged 130 to 150 days, with a mean weight of $360.44 \pm 17 \mathrm{~g}$, obtained from the Paraná Technology Institute were used. For the second stage, 54 male Wistar rats (Rattus norvegicus albinus, Rodentia mammalia) aged 150 days, with a mean weight of $353 \pm 22 \mathrm{~g}$, obtained from the same institution were used. The animals were housed in polypropylene boxes appropriate for the species at the Laboratory of Surgical Technique and Experimental Surgery, Faculty of Medicine, Federal University of Paraná. The animals were maintained under natural light/dark and humidity conditions, without artificial regulation, at a controlled temperature of $20 \pm 2^{\circ} \mathrm{C}$. 
Stage one - The rats were divided into two groups: the control group ( 8 animals) was used to establish reference values and the experimental group (60 animals) submitted to occlusion of the common bile duct was used to determine biochemical alterations after occlusion. The latter group was subdivided into 10 lots of 6 rats each, which were evaluated at 1, 2, 3, 4, 5, 6, 7, 10, 15 and 21 days after occlusion.

On the day of assessment, blood was collected by cardiac puncture under anesthesia for the determination of coagulation time, prothrombin time, and total and fractional bilirubin. Prothrombin time was determined by the one-stage method (Quick's test, Replastin ${ }^{\circledR}$ ) and bilirubin by a colorimetric diazo-assay $\left(\right.$ Labtest $\left.^{\circledR}\right)$. After blood collection, the animals were sacrificed and liver biopsies were obtained by laparotomy. Liver samples fixed in 10\% formalin were submitted to histological preparation and hematoxylin-eosin stained sections were examined under a light microscope.

Stage two - The 54 rats were divided into a control group (30 animals) and an experimental group (24 animals). All animals were submitted to two surgical interventions under sulfur ether inhalation. In the first surgery, after trichotomy, disinfection of the ventral abdominal wall and median laparotomy, rats of the experimental group had their main bile duct sectioned between ligatures and the main stump was wrapped with a 3.0 nonabsorbable nylon monofilament up to its origin as described by Castro e Silva Jr and Mazzeto ${ }^{13}$. The control group was submitted to the same interventions, with the bile duct being manipulated but not interrupted. The animals were then submitted to laparorrhaphy with continuous stitching with 4.0 monofilament nylon sutures on two planes.

After 72 hours, the animals were again anesthetized and submitted to trichotomy of the dorsal region. The circumference of the wound whose center was the midline below the scapulae and above the upper limit of the ilium was then outlined, and the skin and subcutaneous layer delimited by the drawing were excised with a N. ${ }^{\circ} 11$ surgical knife. The drawing of the wound was transferred to transparent graph paper, thus obtaining the real size of the wound at time zero.

The wounds were cleaned daily with $0.9 \%$ sodium chloride solution and received an occlusive dressing.

New measurements of the wound areas were made on postoperative days 3, 7, 10 and 14 . These areas were transferred by means of a 100-dpi resolution scanner to a computer which 
calculated their size using an integral differential calculation program and the individual percent reduction in wound size was recorded for each animal.

One-third of the control animals and one-third of the icteric animals were selected by drawing lots for sacrifice on postoperative day 3, 7 and 14, when the surgical wound was excised leaving a 1-cm margin of normal skin. The specimens obtained were stretched out on filter paper and sent for histological processing. The material was cut into 4- $\mu \mathrm{m}$ thick sections and stained

with Sirius Red for the determination of collagen content ${ }^{14}$. The histological sections were examined under a polarized light microscope, and the images were captured with a Sony camera, transmitted to a color monitor, digitalized and analyzed using the Optimas 6.0 for Windows software. Thick and strongly birefringent collagen fibers show an orange to red color and consist of collagen I, while collagen III is represented by fine and dispersed, weakly birefringent fibers of green color. The sum of the two types of collagen provided the percentage of total collagen in the area studied. Three fields were analyzed per histological section and the mean was calculated.

The results were analyzed statistically by the student t-test. A level of p ? 0.05 or $5 \%$ was considered for rejection of the null hypothesis.

\section{Results}

Stage one - Elevated mean plasma bilirubin concentrations were observed from the first day on, with a maximum peak reached on days 4 and 5 , followed by a decrease and stabilization (Table $1)$.

Prothrombin time was found to be altered at all time points studied, with a significant difference being observed between day 3 and day 5 (Table 2).

The initial weight of control animals was 253.6 ? $33.01 \mathrm{~g}$ and the initial weight of experimental animals was 248.3 ? $22.53 \mathrm{~g}$, with this difference being nonsignificant $(\mathrm{p}=0.1799)$. 
Stage two - The mean area of the surgical wounds at time zero was $252.36 ? 21.16 \mathrm{~mm}^{2}$ for the control group and $245.93 ? 21.53 \mathrm{~mm}^{2}$ for the experimental group, with the difference being non significant $(\mathrm{p}=0.1397)$.

The wounds of the control group were smaller than those of the icteric group at the four time points analyzed. On postoperative day 3, the mean residual area was $79.62 \%$ for the control group and $84.05 \%$ for the icteric group ( $\mathrm{p}=0.0366)$. On day 7 , the mean residual area was $65.81 \%$ for the control group and $75.69 \%$ for the icteric group $(\mathrm{p}=0.0054)$. On day 10 , the mean residual area was $32.85 \%$ for the control group and $57.30 \%$ for icteric group $(\mathrm{p}=0.000003)$. On day 14 , the mean area of the residual wound was $9.35 \%$ for the control group and $18.17 \%$ for the icteric group ( $p=0.00003$ ). The same was observed when only the group that participated in the four time points was analyzed.

TABLE 1 - Mean plasma bilirubin concentration $(\mathrm{mg} / \mathrm{dl})$ and standard deviation obtained for the control group and for the experimental group on different days after bile duct occlusion.

\begin{tabular}{|c|c|c|c|c|c|c|c|c|c|c|c|c|}
\hline & & \multirow{2}{*}{$\begin{array}{l}\text { Control } \\
\text { Group }\end{array}$} & \multicolumn{10}{|c|}{ Group with bile obstruction } \\
\hline & & & Day 1 & Day 2 & Day 3 & Day 4 & Day 5 & Day 6 & Day 7 & Day 10 & Day 15 & Day 21 \\
\hline \multirow[t]{3}{*}{ DB } & Mean & 0,38 & 5,72 & 7,26 & 8,39 & 8,73 & 9,06 & 7,17 & 6,04 & 5,95 & 5,72 & 5,02 \\
\hline & SD & 0,039 & 0,488 & 0,669 & 1,071 & 0,525 & 0,845 & 0,186 & 0,734 & 0,67 & 0,442 & 0,338 \\
\hline & $\% S D$ & 10,26 & 8,85 & 9,21 & 12,76 & 6,01 & 9,33 & 2,59 & 12,15 & 11,26 & 7,73 & 6,73 \\
\hline \multirow[t]{3}{*}{ IB } & Mean & 0,22 & 1,18 & 1,45 & 1,55 & 1,32 & 1,26 & 1,17 & 1,58 & 1,27 & 1,43 & 1,48 \\
\hline & SD & 0,039 & 0,172 & 0,165 & 0,16 & 0,211 & 0,167 & 0,217 & 0,065 & 0,141 & 0,185 & 0,077 \\
\hline & $\% S D$ & 17,73 & 14,58 & 11,38 & 10,32 & 15,98 & 13,25 & 18,55 & 4,11 & 11,1 & 12,94 & 5,2 \\
\hline \multirow[t]{3}{*}{ TB } & Mean & 0,6 & 6,9 & 8,71 & 9,94 & 10,05 & 10,32 & 8,34 & 7,62 & 7,22 & 7,15 & 6,6 \\
\hline & SD & 0,074 & 0,857 & 0,862 & 1,024 & 0,442 & 1,029 & 0,305 & 0,775 & 0,757 & 0,586 & 0,41 \\
\hline & $\% S D$ & 12,33 & 12,42 & 9,89 & 10,3 & 4,4 & 9,98 & 3,66 & 10,17 & 10,48 & 8,19 & 6,21 \\
\hline
\end{tabular}


TABLE 2 - Mean prothrombin time and standard deviation obtained for the control group and for the group with bile obstruction on different days after surgery.

\begin{tabular}{|lcccccccccccc|}
\hline & $\begin{array}{c}\text { Control } \\
\text { Group }\end{array}$ & Day 1 & Day 2 & Day 3 & Day 4 & Day 5 & Day 6 & Day 7 & Day 10 & Day 15 & Day 21 \\
& & & & & & & & & & & \\
Mean & 99 & 91 & 84 & $\mathbf{5 6 , 4}$ & $\mathbf{5 0 , 6}$ & $\mathbf{5 4 , 2}$ & 69 & 75,6 & 79,6 & 82 & 83,2 \\
SD & 2,34 & 8,21 & 6,52 & 6,99 & 6,07 & 5,54 & 6,52 & 6,27 & 3,47 & 4.47 & 3,84 \\
$\%$ SD & 2,36 & 9,02 & 7,76 & 12,39 & 11,99 & 10,22 & 9,45 & 8,29 & 4,36 & 5,45 & 4,61 \\
\hline
\end{tabular}

Significant differences in total collagen and collagen fractions were observed on days 3,7 and 14 (Table 3).

TABLE 3 - Mean percent area of the wound occupied by collagen at the three time points studied.

\begin{tabular}{|c|c|c|c|c|c|c|c|c|}
\hline & & \multicolumn{2}{|c|}{ Collagen I } & & \multicolumn{2}{|c|}{ Collagen III } & \multicolumn{2}{|c|}{ Total collagen } \\
\hline & & Control & Icterric & & Control & Icteric & Control & Icteric \\
\hline \multirow[t]{3}{*}{ Day 3} & Mean & 11,84 & 11,06 & & 30,68 & 22,45 & 42,52 & 33,89 \\
\hline & SD & 3,01 & 3,25 & & 5,84 & 3,63 & 6,31 & 5,55 \\
\hline & $\% S D$ & 25,46 & 29,38 & & 19,03 & 16,17 & 14,84 & 16,38 \\
\hline \multirow[t]{3}{*}{ Day 7} & Mean & 18,3 & 11,61 & & 35,77 & 24,63 & 54,07 & 36,23 \\
\hline & SD & 5,2 & 2,85 & & 8,07 & 5,09 & 7,57 & 7,26 \\
\hline & $\% S D$ & 28,41 & 24,57 & & 22,56 & 20,65 & 14,02 & 20,04 \\
\hline \multirow[t]{3}{*}{ Day 14} & Mean & 18,37 & 11,65 & & 39,27 & 24,77 & 57,64 & 36,42 \\
\hline & SD & 1,49 & 2,3 & & 7,05 & 3,7 & 7,28 & 5,45 \\
\hline & $\% S D$ & 8,12 & 25,73 & & 17,94 & 25,73 & 12,64 & 14,96 \\
\hline \multicolumn{2}{|l|}{$t$ teste } & day 3 & & day 7 & & day 14 & & \\
\hline \multicolumn{2}{|c|}{ collagen I } & 0,3033 & & 0,0014 & & 6E-06 & & \\
\hline \multirow{2}{*}{\multicolumn{2}{|c|}{$\begin{array}{l}\text { collagen III } \\
\text { Total collagen }\end{array}$}} & 0,0016 & & 0,001 & & $3 E-06$ & & \\
\hline & & 0,0039 & & 0,00002 & & $2 \mathrm{E}-06$ & & \\
\hline
\end{tabular}

\section{Discussion}


Extra hepatic biliary obstruction is known to cause jaundice accompanied by alterations in prothrombin time $e^{7,9}$. In the present study, increased serum bilirubin levels were observed after 24 hours, which further increased gradually until reaching maximum concentrations between day 3 and day 5 , followed by a decline and remaining stable thereafter at $7 \mathrm{mg} / \mathrm{dl}$ up to day 21 . The alterations in prothrombin time followed the changes in bilirubin. Based on these alterations, day 3 after the induction of jaundice was chosen for introducing a wound on the back of the animals which was left to heal by second intention.

Jaundice has been repeatedly recognized as a factor impairing surgical wound healing, although controversy still exists. Keill et al (1973) reported a similar number of abdominal wound dehiscences in icteric and anicteric patients ${ }^{1}$, but dehiscences and hernias have been more frequently observed in icteric patients ${ }^{2-4}$. Grande et al (1990) demonstrated an association between jaundice and a higher frequency of abdominal wound healing complications, but called attention to the fact that this was only true for patients with malignant disease ${ }^{5}$.

Hyperbilirubinemia has been shown to exert some effects on wound healing. Migration of reticuloendothelial cells and fibroblasts is known to be reduced in jaundiced rats which show deficient collagen synthesis ${ }^{6}$. A prolonged inflammatory reaction with delayed neovascularization has also been described ${ }^{7}$. The addition of bilirubin to fibroblast cultures led to a reduction in the replication rate of these cells ${ }^{10}$. More recently, Dawiskiba et al (2000) observed in jaundiced rats that both the early and late healing phases were affected, leading to a loss of resistance of the wounds accompanied by reduced proliferation of fibroblasts and endothelial cells, as well as a low collagen concentration ${ }^{11}$.

In a study carried out in our laboratory using jaundiced rats with skin wounds treated by first intention, we observed a lower collagen concentration in the wounds of these animals accompanied by delayed maturation ${ }^{12}$.

Dehiscences are among the disorders observed in wound healing by second intention. We did not find any study on this process in patients or animals with jaundice. In the present study, delayed wound contraction and slower collagen deposition and maturation were observed in jaundiced rats.

In conclusion, jaundice delays collagen deposition and maturation and wound contraction in wounds left to heal by second intention. 


\section{References}

1. Keill RH, Keitzer WF, Nichols WK, Henzel J, DeWeese MS. Abdominal wound dehiscence. Arch Surg 1973; 106:573-7.

2. Ellis H, Heddle R. Does the peritoneum need to be closed at laparotomy? Br J Surg 1977;64:733-6.

3. Irvin TT, Vassilakis JS, Chattopadhyay DK, Greaney MG. Abdominal wound healing in jaundiced patients. Br J Surg1978; 65:521-2.

4. Armstrong CP, Dixon JM, Duffy SW, Elton RA, Davies GC. Wound healing in obstructive jaundice. Br J Surg 1984; 71:267-70.

5. Grande L, Garcia-Valdecasas JC, Fuster J, Visa J, Pêra C. Obstructive jaundice and wound healing . Br J Surg 1990; 77:440-2.

6. Lee E. The effect of obstructive jaundice on the migration of reticulo-endothelial cells and fibroblasts into early experimental granulomata. Br J Surg 1972; 59:875-7.

7. Bayer I, Ellis H. Jaundice and wound healing: an experimental study . Br J Surg 1976; 63:392-6.

8. Than T, McGee JD, Sokhi GS, Patrick RS, Blumgart LH. Skin prolyl hydroxylase in patients with obstructive jaundice. Lancet 1974; 807-8.

9. Greaney MG, Van Noort RV, Smythe A, Irvin TT. Does obstructive jaundice adversely effect wound healing? Br J Surg 1979; 66:478-81.

10. Taube M, Elliot P, Ellis H. Toxicity of bilirubin and bilirubin diglucuronide to rat tissue culture fibroblasts. Eur J Surg 1988; 20:190-4.

11. Dawiskiba J, Kwiatkowska D, Zimecki M, Kornafel P, Tyran W, Czapinka E, Wozniak Z. The impairment of wound healing process is correlated with abnormalities of TNFalpha production by peritoneal exudates cells in obstructive jaundice rats. HPB Surg 2000; 11:311-8.

12. Biondo-Simões MLP, Greca FH, Ioshii SO, Weingärtner J, Guirello CM, Martynetz FA. O papel da icterícia na cicatrização da parede abdominal de ratos. Acta Cir Bras 2001; 16 (Suppl 2):51-55.

13. Castro e Silva Jr O, Mazzetto S. Uma nova técnica operatória para indução experimental de cirrose biliar secundária . Acta Cir Bras 1991; 6(suppl 1):42. 
14. Junqueira LC, Cossermelli W, Brentani R. Differential staining of collagen type I, II and III by Sirius Red and polarization microscopy. Arch Histol (Jpn) 1978; 41:267-74.

Correspondence:

Maria de Lourdes Pessole Biondo-Simões

Rua Ari José Valle, 1987

82030-000 Curitiba - Paraná

Tel/Fax: (41)297-4359

biondo@avalon.sul.com.br

Data do recebimento: 02/03/2004

Data da revisão: 24/03/2004

Data da aprovação: 07/04/2004

Conflict of interest: none

Financial source: none

\section{How to cite this article:}

Biondo-Simões MLP, Araújo CFR, Lima JHF, Ferreira M, Bonardi MA. Jaundice in second intention wound healing in rats. Acta Cir Bras [serial online] 2004 May-Jun;19(3). Available from URL: http://www.scielo.br/acb [also in CD-ROM]. 